\title{
PAK GEREJA DALAM KONTEKS LINGKUNGAN HIDUP SUATU REFLEKSI TERHADAP MARKUS 16:15
}

\author{
Sozawato Telaumbanua \\ Universitas Kristen Indonesia \\ soza.wate@gmail.com
}

\begin{abstract}
Abstrak
Mengabarkan Injil merupakan salah satu tugas gereja (orang Kristen) yang paling penting dan paling mendasar. Pekabaran Injil seringkali dipahami oleh gereja sebagai upaya untuk menambahkan jumlah anggota dalam gereja, sehingga pekabaran Injil hanya dibatasi kepada manusia. Pekabaran Injil yang benar yang diajarkan oleh Yesus bukanlah seperti apa yang dipahami oleh gereja saat ini. Dalam Markus 16:15 menjelaskan bahwa pekabaran Injil tidak hanya dibatasi kepada manusia, tetapi pekabaran Injil mencakup seluruh makhluk yang diciptakan oleh Allah. Seharusnya gereja pada saat ini mulai melihat situasi yang sedang terjadi di sekitarnya, salah satunya mengenai kerusakan lingkungan hidup yang membawa dampak bagi seluruh makhluk/ciptaan. Kepedulian gereja terhadap kerusakan lingkungan hidup, yang semakin hari semakin memprihatinkan dan banyak menelan korban, sebenarnya merupakan salah satu cara pekabaran Injil yang baik dan relevan pada masa kini. Hal ini bisa dilakukan dengan memberikan pendidikan bagi jemaat tentang bagaimana seharusnya sikap orang Kristen terhadap ciptaan Tuhan lainnya. Untuk menjawab permasalahan tersebut, maka penulis menggunakan metode penelitian pustaka, yakni membandingkan berbagai literatur, baik itu buku-buku, artikel, maupun jurnal yang berkaitan dengan pembahasan di atas. Tujuan dari tulisan ini adalah untuk memberi pemahaman sekaligus menyadarkan gereja akan pentingnya pendidikan agama Kristen yang berkenaan dengan lingkungan hidup. Melalui pendidikan, gereja membekali setiap anggota jemaatnya serta menyadarkan mereka bahwa mereka memiliki tanggung jawab terhadap kerusakan lingkungan hidup.
\end{abstract}

Kata Kunci: Gereja, Ekologi, Pekabaran Injil, Pendidikan Agama Kristen

\begin{abstract}
Preaching the Gospel is one of the most important and most basic (Christian) church duties. The gospel message is often understood by the church as an effort to increase the number of members in the church, so that the gospel message is limited to humans. The true gospel message taught by Jesus is not what is understood by the church today. In Mark 16:15 it explains that the gospel message is not only limited to humans, but the gospel message includes all creatures created by God. At this time the church should begin to see the situation that is happening around it, one of which concerns the environmental damage that has an impact on all creatures. The church's concern for environmental damage, which is increasingly apprehensive and has claimed many lives, is actually one of the best and most relevant methods for evangelism today. This can be done by giving the congregation education about how
\end{abstract}


Christians should behave towards other God's creations. To answer these problems, the authors use library research methods, namely comparing various literatures, both books, articles, and journals related to the discussion above. The purpose of this paper is to provide understanding and make the church aware of the importance of Christian religious education relating to the environment. Through education, the church equips each member of the congregation and makes them aware that they have a responsibility for the environment.

\section{Keywords: Church, Ecology, Evangelism, Christian Religious Education}

\section{Pendahuluan}

Bumi yang didiami oleh manusia saat ini sedang mengalami krisis lingkungan hidup yang semakin hari semakin hebat kerusakannya. Salah satu bukti nyata adalah krisis lingkungan hidup yang seringkali terdengar dan mungkin sedang dirasakan saat ini adalah masalah global warming (pemanasan global), hal ini bisa dilihat dengan perubahan iklim yang begitu ekstrim. Selain pemanasan global, bencana alam juga merupakan ancaman yang paling menakutkan. Dalam beberapa tahun terakhir bisa terlihat berbagai bencana alam yang silih berganti terjadi di berbagai belahan dunia, dan khususnya di Indonesia, diantaranya: gempa bumi, tsunami, banjir, tanah longsor, dan lain sebagainya. ${ }^{1}$ Bencana alam tersebut mengancam setiap makhluk yang ada di planet bumi ini, bahkan sudah tidak terhitung berapa banyak nyawa yang telah hilang akibat bencana alam tersebut.

Bencana alam merupakan salah satu masalah yang tak kunjung usai. Di Indonesia sendiri hampir setiap tahun bencana melanda bumi pertiwi. Di awal tahun 2020 ini saja sudah berapa nyawa yang hilang karena bencana alam. Banyak spekulasi yang timbul dari bencana alam yang terjadi, ada yang berkata bahwa ini

1 Satrio Wahono, "Etika Bumi dan Krisis Lingkungan", Tempo.com, 2020, diakses pada tanggal $01 \quad$ April 2020. https://kolom.tempo.co/read/1313188/etika-bumidan-krisis-lingkungan/full\&view=ok adalah tanda-tanda akhir zaman, ada juga yang berpendapat bahwa ini hanya gejala alam biasa. Menurut penulis, meskipun bencana alam adalah bagian dari gejala alam, tetapi harus diakui bahwa bencana alam juga terjadi akibat dari ulah manusia.

Bukan tanpa alasan penulis berpendapat demikian. Jika memperhatikan gaya hidup manusia, maka bisa terlihat bahwa banyak manusia yang gaya hidupnya tidak ramah lingkungan, sebagai akibatnya keseimbangan ekosistem menjadi terganggu. Robert P. Borrong, dalam bukunya Etika Bumi Baru mengatakan: "kerusakan lingkungan hidup dipicu oleh tindakan atau tingkah laku manusia yang bersifat menguasai dan sekaligus mengeksploitasi alam ini". ${ }^{2}$ Manusia memiliki peran dalam menentukan kelestarian lingkungan hidup. Namun sayang, seringkali apa yang dilakukan manusia tidak diimbangi dengan pemikiran akan masa depan, atau kehidupan generasi berikutnya. Banyak kemajuan yang diraih oleh manusia membawa dampak buruk terhadap kelangsungan lingkungan hidup dan berakibat buruk terhadap generasi berikutnya.

Berkenaan dengan situasi yang seperti ini, maka perlu adanya kepedulian dari berbagai pihak, baik instansi

\footnotetext{
${ }^{2}$ Robert P. Borrong, Etika Bumi Baru (Jakarta: BPK Gunung Mulia, 2009), 31-38.
} 
pemerintah, swasta dan individu, untuk bersama-sama memberikan perhatian secara khusus terhadap masalah lingkungan hidup ini. Harus diakui bahwa sudah mulai ada usaha-usaha yang telah dilakukan untuk mengatasinya, baik oleh pemerintah maupun swasta seperti gereja, dunia usaha dan perorangan. Namun hal ini masih belum merata karena kurangnya kesadaran masyarakat akan hal itu. P. Nasution yang merupakan salah seorang tokoh yang memiliki beban terhadap masalah lingkungan hidup, mengatakan bahwa upaya untuk mencegah kerusakan lingkungan hidup dapat dilakukan oleh setiap orang asal ada kemauan/kepedulian terhadap lingkungan. Salah satu contoh adalah merubah kebiasaan hidup yang serba mewah serta melakukan penghijauan di pekarangan rumah atau di lahan-lahan yang kosong. ${ }^{3}$ Menurut Ezichi A. Ituma, untuk mencegah semakin parahnya kerusakan lingkungan, badan internasional harus membuat satu kesepakatan yaitu agar setiap negara, khusunya negara-negara maju mengurangi emisi gas rumah kacanya. Selain itu para rohaniawan (pendeta), harus diperlengkapi dan kemudian harus memberikan pencerahan kepada umat untuk menjaga dan memelihara lingkungan hidup yang diciptakan oleh Allah. ${ }^{4}$

Harus diakui bahwa gereja sendiri masih belum maksimal dalam menangani ataupun berkontribusi langsung dalam menangani kerusakan lingkungan hidup ini. Gereja tidak bisa menutup mata dengan situasi yang terjadi di sekitarnya.

\footnotetext{
${ }^{3}$ P. Nasution, "Pemanasan Global dan upayaupaya sederhana dalam mengantisipasinya", 2009, diakses pada tanggal 01 April 2020. http://www.gogreenindonesiaku.com/green_opini on1.php

${ }^{4}$ Ezichi A. Ituma, "Christocentric Ecotheology and Climate Change", Open Journal of Philosophy Vol.3 No.1a (Februari 2013): 129-130.
}

Oleh karenanya melalui tulisan ini, penulis hendak menekankan bahwa perlu adanya pendidikan agama Kristen di dalam gereja yang berkenaan dengan lingkungan hidup, sehingga dengan demikian gereja bisa berkontribusi dalam menangani krisis lingkungan hidup.

\section{Metode}

Dalam penulisan ini, penulis akan menggunakan metode penelitian pustaka, yakni membandingkan berbagai literatur, baik itu buku-buku, artikel, jurnal maupun hal-hal yang dikaji dan dipublikasikan melalui media-media masa (misalnya majalah, koran, internet, dan lain-lain) yang berkaitan dengan pembahasan di atas.

\section{A. Sikap Gereja terhadap Masalah Lingkungan Hidup}

1. Pengertian Gereja

Jika berbicara tentang Gereja, maka yang terbayang dalam pikiran banyak orang adalah suatu bangunan atau gedung tempat kebaktian ataupun suatu struktur organisasi umat Kristiani yang telah berlangsung sepanjang sejarah Gereja Kristen. Lalu apa sebenarnya arti gereja itu sendiri? Secara etimologi, Gereja berasal dari kata bahasa Potugis Igreja, yang berasal dari bahasa Yunani

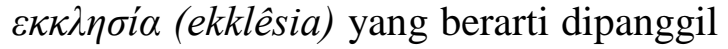
keluar ( $k=$ keluar; klesia dari kata kaleo= memanggil). ${ }^{5}$ Gereja diartikan sebagai perkumpulan orang-orang yang dipanggil dari kegelapan kepada terang-Nya yang ajaib. Jadi pada awal mulanya, gereja lebih identik dengan orang yang telah percaya kepada Yesus, bukan kepada gedung atau organisasinya. Menurut Kamus Besar Bahasa Indonesia, Gereja adalah: tempat ibadah umat Kristen,

\footnotetext{
${ }^{5}$ Bigman Sirait, Gereja yang Membumi (Jakarta: Yapama, 2015), 3.
} 
gedung (rumah) tempat berdoa dan melakukan upacara agama Kristen; badan (organisasi) umat Kristen yang sama kepercayaan, ajaran, dan tata cara ibadahnya. Milllard J. Erickson mengatakan, gereja didirikan Tuhan, bukanlah demi keberadaan gereja itu sendiri, melainkan untuk melanjutkan pelayanan Tuhan di dunia. Erickson berkata bahwa jantung pelayanan gereja dan yang memberi bentuk segala aktifitas gereja adalah: Injil. ${ }^{6}$ Jadi, Gereja adalah perkumpulan orang-orang yang percaya kepada Yesus yang telah terorganisasi dan terstruktur, serta memiliki tugas mulia yang berasal dari Allah sendiri. Gereja memiliki 3 fungsi utama:

- Koinonia (besekutu), di mana gereja dipanggil dalam persekutuan dengan Dia. Gereja adalah pertama-tama persekutuan dengan Kristus, akan tetapi persekutuan dengan Kristus selalu berarti pula dengan persekutuan dengan manusia lain. Gereja sebagai tubuh Kristus sehati sepikir, berjuang untuk iman yang ditimbulkan oleh Injil, saling memahami, memperhatikan dan melayani demi kepentingan bersama (Flp. 1:27; 2:4; 1 Kor. 12:27).

- Marturia (bersaksi) adalah menyatakan apa yang diperbuat oleh Allah melalui Yesus Kristus bagi keselamatan manusia (Mat. 28:19-20; Kis. 1:8). Sebelum kenaikannya Yesus memberi perintah kepada murid-murid-Nya untuk menjadi saksi bagi Kristus mulai dari Yerusalem sampai ke ujung Bumi. Kristus menuntut setiap orang percaya menjadi saksi bagi-Nya.

- Diakonia (melayani), merupakan pelayanan kasih, terutama di meja

\footnotetext{
${ }^{6}$ BP, “Gereja: Arti dan Perannya”, 2013, diakses $01 \quad$ April 2020. http://www.sarapanpagi.org/gereja-arti-danperannya-vt6452.html
}

makan yang bertujuan untuk penelenggaraan pemiliharaan hidup. Hal ini merupakan suatu cara untuk memuliakan Allah (1 Ptr 2:12). Yesus mengajak gereja untuk mengikuti teladan-Nya dengan persekutuan melayani dengan kerendahan hati satu sama lain. Pemerintahan Yesus adalah pelayanan Diakonia, Ia melayani bukan hanya dengan perkataan tapi juga dengan perbuatan. PerkataanNya adalah perbuatan dan perbuatanNya adalah perkataan.

Dalam Perjanjian Baru, kata Gereja sering sekali dipakai untuk menggambarkan sifat dari gereja atau jemaat itu sendiri. Berikut penulis uraikan beberapa gambaran yang dikaitkan dengan gereja, antara lain:

\section{a. Gereja Universal}

Ini artinya bahwa gereja terdiri dari semua orang yang memiliki hubungan pribadi dengan Yesus Kristus. Di sini digambarkan bahwa seluruh jemaat yang percaya dan mengakui Yesus sebagai Tuhan dan Juruselamat pribadi mereka, hal ini merupakan bagian dari gereja universal, sehingga tidak ada perbedaan di antara para jemaat karena Kristus telah menjadi pemersatu mereka. Gambaran mengenai Gereja sebagai Gereja Universal dapat ditemukan dalam kitab 1 Korintus 12:13-14, yang mengatakan: "Sebab dalam satu Roh kita semua, baik orang Yahudi, maupun orang Yunani, baik budak, maupun orang merdeka, telah dibaptis menjadi satu tubuh dan kita semua diberi minum dari satu Roh..."

\section{b. Gereja Lokal}

Artinya bahwa gereja lokal ini merupakan perkumpulan/kelompok orang yang bertemu dalam sebuah tempat/lokasi secara khusus. Kalua dilihat secara 
berkeseinambungan, maka gereja lokal ini merupakan bagian dari Gereja yang Universal di atas. Dalam PB, yang dimaksud Gereja Lokal adalah jemaatjemaat di masing-masing kota pada zaman PB. Beberapa tulisan Paulus dalam PB merupakan surat kiriman kepada beberapa jemaat lokal, antara lain jemaat yang berada di Roma, Korintus, Galatia, Efesus, Filipi, Kolose, Tesalonika, Berea, Tiatira, dan masih banyak yang lain. Hal ini bisa dilihat salah satunya dari surat Paulus kepada jemaat di Galatia 1:1-2, yang berbunyi: "Dari Paulus, seorang rasul, ... dan dari semua saudara yang ada bersama-sama dengan aku, kepada jemaat-jemaat di Galatia."

\section{c. Gereja sebagai Sebuah Perhimpunan/ Perkumpulan}

Gereja sebagai perhimpunan/ perkumpulan artinya bahwa di jemaat tersebut ada perhimpunan yang terdiri dari individu-individu yang memiliki suatu tujuan bersama. Tentunya perhimpunan/ perkumpulan ini terdiri dari mereka yang telah percaya dan telah menerima Yesus di dalam hidupnya. Sebagai contohnya bisa dilihat di dalam Surat 1 Korintus 11:18 “...bahwa apabila kamu berkumpul sebagai jemaat..."

Dalam perkembangan berikutnya, gereja disebut sebagai organisasi keagamaan yang universal, walaupun pada dasarnya organisasi ini merupakan mitra Allah di tengah-tengah dunia ini, di mana gereja berada dalam konteks/lingkungan tertentu. Oleh karenanya gereja harus bisa menyesuaikan diri dalam konteks tersebut, karena di dalam situlah gereja hadir dan berkarya. ${ }^{7}$ Dalam hubungan

\footnotetext{
7 Silvester Adinuhgra, "Ekspoitasi Lingkungan Hidup dalam Perspektif Sollicitudo Rei Socialis (Sebuah Bentuk Keprihatinan Gereja)" Jurnal Sepakat Vol.3, No.1 (Desember 2016): 84.
}

tugas sosial ini, kita harus selalu waspada agar tugas gereja melayani sosial dunia tidak dilakukan dengan mengorbankan tugas gereja, yakni menginjili dunia. Dewasa ini, para pemimpin Kristen cenderung memusatkan perhatian utama pada kebutuhan-kebutuhan fisik atau materi umat manusia. Mereka menghendaki agar gereja-gereja di seluruh dunia ikut berperan aktif dalam usaha mengatur kembali struktur sosial, politik, ekonomi masyarakat dunia dewasa ini, yang tidak adil, yang menurut mereka menjadi penyebab dari kemelaratan dan ketidakmampuan umat manusia yang tertindas. Sedangkan Alkitab mengajar bahwa semua manusia, baik yang mampu maupun yang tidak mampu, baik yang kaya maupun yang melarat, baik yang berkuasa maupun yang tidak berkuasa, semuanya sebagai orangorang yang belum percaya Kristus, samasama miskin dan sama-sama tidak mampu di hadapan Allah.

\section{Peran Gereja}

Melihat semakin kritisnya lingkungan hidup di seluruh dunia, dan khususnya di Indonesia, maka Gereja harus terpanggil memberikan kontribusi untuk mengatasi masalah tersebut. Gereja harus sadar, bahwa kerusakan lingkungan bersumber dari perilaku manusia. Manusia mesti memahami bahwa bumi ini menjadi tanggungjawab mereka sebagai orang percaya kepada Allah. Manusia harus mempertanggungjawabkannya segala hal yang manusia lakukan terhadap ciptaan lainnya kepada Allah sebagai pencipta bumi beserta segala isinya. Oleh sebab itu, pelestarian lingkungan hidup ini seharusnya bagian yang tidak terpisahkan dari penginjilan yang dilakukan oleh gereja sebagai persekutuan orang percaya. Jikalau seseorang telah hidup di dalam Kristus dan telah menerima Injil Kristus, 
semestinya mereka menjadi pelopor untuk melestarikan lingkungan hidup. Menurut H. Martensen, yang dikutip oleh A.A. Sitompul, "hidup menurut Kristus adalah kasih kekristenan." 8 Menurutnya kasih kekristenan ini juga termasuk kepada ciptaan TUHAN yang lain, yakni alam/lingkungan hidup manusia.

$$
\text { Mengenai hal tersebut, }
$$

Persekutuan Gereja-gereja di Indonesia (PGI) ikut memberi perhatian terhadap masalah kerusakan lingkungan hidup yang makin hari makin bertambah kerusakannya. Dalam Sidang Raya XII PGI yang dilaksanakan pada tanggal 2130 Oktober 1994 di Jayapura memutuskan agar gereja, khususnya gereja yang ada di Indonesia, memberitakan Injil/kabar sukacita itu kepada segala makhluk (Markus 16:15), termasuk lingkungan hidup yang sedang mengalami kerusakan. PGI pun sampai saat ini terus berusaha melakukan upayaupaya agar setiap orang Kristen peduli terhadap lingkungan hidup. ${ }^{9}$

Tapi dalam kenyataannya, gerejagereja masih kurang peduli dengan keadaan lingkungan hidup yang semakin rusak, padahal gereja bertumbuh dalam keadaan seperti ini. Seharusnya gereja memiliki tugas untuk mengaplikasikan sekaligus mengabarkan Injil Kristus itu kepada ciptaan TUHAN yang lain. Artinya bahwa Injil Kristus ini tidak hanya terbatas bagi manusia sebagai ciptaan yang memiliki kelebihan secara khusus, yaitu berakal, tetapi juga bagi ciptaan TUHAN yang lain. Oleh sebab itu, pemberitaan Injil oleh gereja cakupannya sangat luas. Pembatasan pekabaran Injil oleh Gereja pada masa

\footnotetext{
${ }^{8}$ A.A. Sitompul, Manusia dan Budaya (Jakarta: BPK Gunung Mulia, 2000), 17.

9 MS, "Menggugah Warga Gereja Peduli Lingkungan”, PGI, 2014, diakses 30 Maret 2020. https://pgi.or.id/menggugah-warga-gereja-pedulilingkungan/
}

kini, yang hanya mengkhususkannya kepada manusia saja, merupakan suatu kekeliruan yang dilakukan oleh gereja.

Oleh sebab itu, perlulah gereja melihat kembali apa yang menjadi tugas dan tanggung jawabnya sebagai persekutuan orang percaya dalam dunia ini. Paling tidak ada 3 tugas panggilan gereja, diantaranya: Koinonia (bersekutu), Marturia (bersaksi/ memberitakan Injil), dan Diakonia (melayani). Menurut Robert P. Borrong, "Gereja selaku persekutuan orang percaya tidak hanya bertanggung jawab untuk mewujudkan persekutuan di antara sesama manusia, tetapi juga dengan lingkungan". ${ }^{10}$ Hal senada juga diungkapkan oleh salah seorang tokoh yang bernama Moltmann. Menurut Moltmann, yang dikutip oleh Robbert P. Borrong, "gereja sebagai "Christianity" yang berada tidak untuk kehormatannya sendiri, tetapi untuk kehormatan Kerajaan Allah". 11 Artinya bahwa keberadaan gereja di dalam dunia ini tidak hanya untuk memikirkan hal-hal yang berkaitan dengan dirinya sendiri sebagai suatu komunitas, tetapi juga memikirkan halhal yang ada di sekitarnya. Namun faktanya masih banyak gereja yang sampai saat ini hanya fokus pada urusan internal belaka.

\begin{tabular}{lllr}
\multicolumn{2}{c}{ Keberadaan gereja } & sebagai \\
persekutuan & orang-orang & percaya \\
mengemban & satu & misi & dalam \\
panggilannya & yaitu & mengahadirkan
\end{tabular} shalom (damai sejahtera) di dalam dunia ini. Gereja seharusnya memikirkan halhal yang terjadi di sekelilingnya sekaligus mencari solusi-solusi yang tepat, misalnya saja masalah-masalah lingkungan hidup yang merupakan ancaman bagi manusia dan juga gereja yang bertumbuh di dalamnya. Gereja

\footnotetext{
${ }^{10}$ Robert P. Borrong, dkk. (Peny), Berakar di dalam Dia dan Dibangun di atas Dia (Jakarta: BPK Gunung Mulia, 2010), 124.

${ }^{11}$ Borrong, Berakar di dalam Dia, 258.
} 
harus berperan aktif dalam mencari solusi supaya manusia dan alam mengalami damai sejahtera. Hal ini patut dilaksanakan oleh gereja sebagai bentuk dari pengejewantahan imannya kepada Tuhan sebagai pencipta alam semesta. Solusinya bisa dengan memberikan edukasi/pendidikan kepada warga jemaat tentang bagaimana sikap hidup seorang Kristen dalam menyikapi masalah lingkungan hidup ini.

Jemaat perlu diberikan kesadaran bahwa mereka memiliki tanggung jawab terhadap makhluk ciptaan lainnya karena manusia sebagai ciptaan Allah memiliki kelebihan khusus dari ciptaan Allah lainnya. Manusia memiliki akal budi untuk membedakan mana yang baik dan mana yang tidak baik serta Allah sendiri memberi kuasa kepada manusia untuk mengelola ciptaan Allah lainnya. ${ }^{12}$ Sayangnya, kuasa yang diberikan oleh Allah seringkali disalah artikan oleh manusia, sehingga mereka bertindak sesuka hati demi kepentingan diri sendiri atau kelompoknya.

Dari penjelasan di atas dapat terlihat bahwa gereja memiliki tanggung jawab besar. Oleh sebab itu, pernyataan mengenai gereja hanya memikirkan halhal yang berkaitan dengan surga atau TUHAN, itu merupakan pemikiran yang keliru. Menurut Stott, yang dikutip oleh Haskarlianus Pasang, "Gereja memiliki jati diri "ganda", yakni gereja sebagai umat yang kudus sekaligus umat yang duniawi". ${ }^{13}$ Ini artinya bahwa gereja tidak bisa melepaskan diri dari dunia ini. Dari pandangan Stott tersebut, maka gereja

12 Paulus Erwin Sasmito, "Melestarikan Lingkungan Hidup Secara Komprehensif", Jurnal Orientasi Baru Vol. 24 No.1 (April 2015): 42.

${ }^{13}$ Haskarlianus Pasang, Mengasihi Lingkungan: Bagaimana Orang Kristen, Keluarga dan Gereja Mempraktikkan Kebenaran Firman Tuhan untuk Menjadi Jawaban atas Krisis Ekologi dan Perubahan Iklim di Bumi Indonesia (Jakarta: Perkantas, 2011) 241. harus berdiri seimbang atas jati dirinya itu. Gereja tidak dapat memilih salah satu jatidirinya yang lebih dia utamakan. Apabila gereja hanya mengutamakan salah satu dari jati dirinya ini, maka gereja akan terperosok dalam dua ekstrem. Yang pertama, apabila gereja hanya mengutamakan hal-hal yang berkaitan dengan kekudusannya sebagai umat TUHAN, maka secara tidak sadar gereja telah mengisolasi diri dan kehadirannya tidak relevan bagi dunia di mana gereja berada. Yang kedua, apabila gereja hanya mengutamakan hal-hal yang berkaitan dengan yang duniawi, maka secara tidak sadar gereja telah menutup diri terhadap panggilannya sebagai umat pilihan TUHAN. ${ }^{14}$ Oleh sebab itu jati diri ganda gereja ini saling berkaitan serta harus seimbang dalam aplikasinya oleh gereja.

2. Kepedulian Gereja terhadap Lingkungan sebagai Wujud Pelayanan yang Holistik

Memberikan pendidikan agama Kristen kepada warga jemaat merupakan salah satu tugas gereja yang cukup penting. Pendidikan agama Kristen yang berkaitan dengan lingkungan hidup harus dilakukan oleh gereja. Ketika pendidikan tersebut dilakukan oleh gereja, maka secara tidak langsung gereja telah melakukan pelayanan yang holistik. Holistik/holistis dalam Kamus Besar Bahasa Indonesia mengandung pengertian "keseluruhan sebagai suatu kesatuan lebih penting dari pada satu-satu bagian dari suatu organisme". Berdasarkan pengertian di atas, istilah pelayanan yang holistik adalah pelayanan yang bersifat menyeluruh, tidak terbagi-bagi. Pelayanan yang memandang, memahami, mendekati dan memperlakukan setiap makhluk sebagai satu keseluruhan yang

\footnotetext{
${ }^{14}$ Pasang, Mengasihi Lingkungan, 241.
} 
utuh. Ini merupakan sebuah pengakuan bahwa hakikat manusia dan ciptaan TUHAN yang lain terdiri atas unsurunsur dan aspek-aspek yang berbeda-beda (multidimensional), namun demikian kepelbagaian itu tidak dipahami sebagai yang bersifat dikotomis (dapat dipisahpisahkan atau saling dipertentangankan) ataupun hirarkis (seolah-olah ada unsur yang lebih penting atau lebih mulia dari unsur lainnya).

Istilah pelayanan yang holistik saat ini memang banyak digunakan oleh berbagai kalangan untuk menunjukkan bentuk pelayanannya, namun ada saja kelompok orang yang salah mengartikannya. Salah pengertian yang paling sering mengenai pelayanan holistik adalah anggapan bahwa pelayanan ini adalah pelayanan yang berbentuk pelayanan sosial, sehingga akhirnya ada pengertian bahwa pelayanan holistik adalah pelayanan sosial.

Sebagian besar orang melihat pelayanan holistik sebagai aktivitas yang pertama dari usaha penanaman gereja, berbentuk respon bagi kebutuhan fisik dan sosial dari masyarakat. Sebagian lagi memulai dengan visi dari transformasi individu dan masyarakat dalam seluruh bagian kehidupan spiritual, ekonomi dan sosial dan kemudian megembangkan sebuah strategi yang selaras dengan visi itu. Kelompok yang memulai dengan visi dari transformasi mengakui bahwa ada hubungan dari semua area kehidupan. Pelayanan yang dilakukan harus terintegrasi dan mereka mengakui bahwa berita Injil adalah lengkap yaitu isi berita dan dampaknya. Kelompok ini melihat bahwa tema dari Kerajaan TUHAN adalah pelayanan holistik. Kerajaan TUHAN merupakan isi dari berita Injil dan harus membawa dampak pada seluruh bagian kehidupan manusia. Menurut Yakob Tomatala hakikat misi yang holistik adalah "dapat dijelaskan sebagai "satu yang menyeluruh" yang memiliki kesatuan integral dengan aspekaspek lengkap yang utuh.,"15

Kepedulian terhadap lingkungan merupakan bagian dari misi holistik yang dilakukan oleh gereja. Ketika gereja melaksanakan misi terhadap lingkungan, maka hal itu tidak hanya bermanfaat bagi gereja tersebut, tetapi mencakup seluruh makhluk yang ada di dalamnya. Oleh karena itu pemberitaan kabar sukacita menyentuh aspek pelayanan dasar pada empat dimensi pelayanan yang holistik yaitu : Persekutuan (koinoneo), Pelayanan (diakoneo), Kesaksian (martureo) dan Pemberitaan (kerigma/kerusso). ${ }^{16}$

Dari penjelasan di atas bisa terlihat bahwa gereja memiliki peran aktif dalam mengatasi masalah lingkungan hidup yang makin memprihatinkan. Keterlibatan gereja dalam mengatasi masalah lingkungan hidup merupakan salah satu bentuk pekabaran Injil yang relevan pada saat ini.

\section{B. Markus 16:15 dan Relevansinya terhadap Kerusakan Lingkungan Hidup}

Lalu Ia berkata kepada mereka: "Pergilah ke seluruh dunia, beritakanlah kabar sukacita kepada segala makhluk." Di sini Yesus memberikan suatu perintah kepada para murid untuk meneruskan misi yang sudah dirintis dan sudah dimulai oleh Yesus sendiri. Yesus meminta murid-murid-Nya agar menyampaikan Injil atau Kabar Gembira kepada semua makhluk: manusia, hewan dan tumbuh-tumbuhan. Dengan kata lain, bukan hanya manusia, tetapi hewan dan tumbuh-tumbuhan pun harus ikut bergembira karena keselamatan yang dikerjakan oleh TUHAN melalui Yesus

\footnotetext{
15 Yakob Tomatala, Teologi Misi (Jakarta: YT Leadership Foundation, 2003), 63.

${ }^{16}$ Yakob Tomatala, Teologi Misi, 61-63.
} 
Kristus. Maka tugas pengutusan dari Yesus "Pergilah ke seluruh dunia, beritakanlah Injil kepada segala makhluk", berarti meneruskan atau memperdalam kegembiraan yang sudah ada dalam semua makhluk melalui Injil atau Kabar Baik tersebut.

Dari ayat di atas, penulis melihat bahwa ada 3 poin penting yang sangat ditekankan oleh Yesus, yaitu:

\section{Pergilah ke Seluruh Dunia}

Dalam ayat ini terdapat kata Yunaninya poreuthentes yang merupakan kata perintah, artinya pergilah, berjalanlah. Ini merupakan suatu perintah yang harus dilaksanakan oleh seseorang yang diberi perintah tersebut. Artinya bahwa di sini ada sebuah action/tindakan yang harus dilakukan. Sebelum Yesus terangkat ke surga, Yesus memerintahkan para murid untuk tidak berdiam diri, tetapi mereka harus berbuat sesuatu. Yesus mengutus para murid ke seluruh dunia.

Dalam bahasa Yunani istilah dunia memakai kata kosmos yang berarti dunia. Donald Guthrie mengatakan bahwa kosmos yang dimaksud dalam Injil sinoptik adalah planet bumi yang merupakan dunia materi. ${ }^{17}$ Biasanya arti kosmos semacam ini selalu dikaitkan dengan relasi antara TUHAN dan manusia, di mana TUHAN terlibat dalam hubungan dengan manusia dan dunianya. Menurut Tomatala, kosmos atau dunia bisa diartikan segala sesuatu, akan tetapi fokus utamanya adalah manusia sebagai ciptaan TUHAN yang utama. ${ }^{18}$

Jadi perintah untuk pergi ke seluruh dunia di sini adalah dunia secara keseluruhan, yaitu bangsa-bangsa yang bukan Yahudi serta bangsa

\footnotetext{
17 Donald Guthrie, Teologi Perjanjian Baru 1, (Jakarta: BPK Gunung mulia, 2010), 112.

${ }^{18}$ Yakob Tomatala, Teologi Misi, 81.
}

Yahudi. Yesus menegaskan bahwa kabar sukacita atau kabar keselamatan itu bersifat universal. Bukan hanya terbatas kepada wilayah Israel, tetapi kepada seluruh dunia, yakni menunjuk kepada daerah geografis yang ada di dunia ini.

\section{Beritakan Kabar Sukacita}

Dalam kalimat ini terdapat kata perintah keruxate yang bermakna proklamirkan, beritakan. Kata proklamirkan itu bermakna sebuah kata yang bernada kemenangan. Karena Kristus yang sudah bangkit, menang atas maut itu menjadi inti pusat dari pemberitaan itu. Yang diberitakan adalah euaggelion artinya kabar sukacita atau dalam terjemahan Lembaga Alkitab Indonesia Injil. Sebenarnya kata Injil ini berasal dari bahasa Arab (Ingil) yang diturunkan dari kata Yunani euaggelion yang artinya kabar baik. Jadi Injil yang dimaksud dalam hal ini adalah kabar sukacita.

Kata ini sebenarnya telah dipakai oleh bangsa Yahudi sejak masa Perjanjian Lama. Bagi bangsa Yahudi, kata euaggelion selalu dihubungkan dengan hal-hal yang sifatnya sukacita dan benarbenar terjadi, misalnya mengenai kelahiran anak yang akan mewarisi tahta kemenangan dalam perang, dan lain-lain. Para nabi juga mengatakan bahwa euaggelion itu sendiri yaitu: "mengarah kepada proklamasi penyelamatan pada umumnya dan datangnya zaman keselamatan pada khususnya." 19

Sebagai contohnya adalah nabi Yesaya yang menuliskan dalam kitabnya, yakni dalam Yesaya 61:1: "Roh Tuhan ALLAH ada padaku, oleh karena TUHAN telah mengurapi aku; Ia telah mengutus aku untuk menyampaikan kabar baik kepada orang-orang sengsara, dan

\footnotetext{
${ }^{19}$ Stefan Leks, Tafsir Injil Lukas (Yogyakarta: Kanisius. 2002), 23.
} 
merawat orang-orang yang remuk hati, untuk memberitakan pembebasan kepada orang-orang tawanan, dan kepada orangorang yang terkurung kelepasan dari penjara." Jadi Isi kabar baik menurut nabi Yesaya yaitu pembebasan dan kelepasan. $^{20}$

Senada dengan padangan di atas, maka dalam kitab Perjanjian Baru, khususnya dalam Injil Markus, euaggelion ini lebih mengarah kepada kabar sukacita bahwa TUHAN di dalam Yesus Kristus telah memenuhi janji-janjiNya kepada bangsa Israel serta membuka pintu keselamatan bagi semua umat manusia melalui kematian Yesus di atas kayu salib serta kebangkitan-Nya dari antara orang mati. Pemberitaan kabar sukacita haruslah berpusat kepada Kristus. Pemberitaan kabar sukacita berarti memproklamirkan bahwa Kristus yang sudah bangkit itu berkuasa atas segala sesuatu serta menyediakan keselamatan bagi dunia ini, yakni seluruh ciptaan TUHAN.

\section{Segala Makhluk}

Di sini juga terdapat kata Yunani ktisis yang bisa diartikan ciptaan ataupun makhluk. Makhluk merupakan ciptaan TUHAN dan makhluk ini tidak terbatas hanya manusia saja. Makhluk di sini mencakup manusia, hewan dan tumbuhtumbuhan yang diciptakan oleh TUHAN. Perintah untuk memberitakan kabar sukacita kepada segala mahluk berarti tugas untuk menyebarluaskan kegembiraan/kebaikan atau berbuat baik kepada semua ciptaan TUHAN, yakni manusia, binatang maupun tumbuhtumbuhan, karena itu semua adalah ciptan TUHAN.

Kabar sukacita yang dibawa oleh Yesus tidak dibatasi hanya bagi manusia

${ }^{20}$ C. Groenen, Pengantar ke dalam Perjanjian Baru (Yogyakarta: Kanisius), 72. saja, akan tetapi itu bersifat universal dan merata bagi semua ciptaan TUHAN. Apabila manusia menerima kabar sukacita yang telah diberikan oleh Yesus, maka mau tidak mau ciptaan lain, seperti alam semesta juga mengalaminya. ${ }^{21}$ Menurut Elisa B. Surbakti, "segala makhluk berarti tidak memandang suku, bangsa ras, golongan, tempat atau lokasi." 22 Sedangkan menurut Matthew Henry segala makluk mencakup segala jenis makhluk hidup yang ada di dalam dunia ini. ${ }^{23}$

Dari penjelasan di atas, maka penulis menyimpulkan bahwa makhluk yang dimaksud dalam hal ini lebih kepada seluruh isi dunia ini, baik manusia, hewan maupun tumbuh-tumbuhan. Seluruh makhluk ini harus merasakan dampak dari pengorbanan Yesus yang mati, dikuburkan dan bangkit pada hari yang ketiga.

\section{Implementasi Markus 16:15}

Memberitakan Injil kepada segala makhluk bukan berarti harus berkhotbah kepada tumbuh-tumbuhan atau kepada binatang-binatang. Seringkali orang beranggapan bahwa tidak mungkin mengabarkan Kabar Baik kepada segala makhluk. Menurut penulis pekabaran Injil kepada segala makhluk lebih kepada tindakan nyata yang akan seseorang lakukan. Ketika sikap hidup manusia ramah dengan lingkungan, seperti menjaga kelestarian hutan, mengurangi sampah plastik, dan lain sebagainya, itu sudah bagian dari kabar sukacita yang manusia berikan kepada segala makhluk yang ada di sekitar kita. Dengan menjaga

\footnotetext{
${ }^{21}$ Stefan Leks, Tafsir Injil Lukas (Yogyakarta: Kanisius, 2003), 510.

${ }^{22}$ Elisa B. Surbakti, Benarkah Yesus Juruselamat Universal? (Jakarta: BPK Gunung Mulia, 2008), 33.

${ }^{23}$ Matthew Henry, Tafsiran Matthew Henry: Injil Markus, (Surabaya: Momentum, 2011), 394.
} 
kelestarian hutan, maka manusia dan makhluk lainnya bebas dari bencana erosi maupun banjir.

Gereja memiliki tanggung jawab besar untuk mengimplementasikan Markus 16:15 ini agar keutuhan ciptaan TUHAN tetap terjaga. Dari penelitian ini, penulis melihat ada kelalaian yang dilakukan oleh gereja dalam menjalankan tugasnya di tengah-tengah dunia ini, diantaranya:

- Harus diakui bahwa masih banyak gereja yang memahami bahwa Kabar Sukacita/Injil yang dibawa oleh Yesus hanya dikhususkan kepada manusia saja. Menurut penulis ini merupakan pandangan yang salah bagi gereja. Seharusnya kabar Sukacita itu mestinya dirasakan oleh segala makhluk yang ada di muka bumi ini.

- Gereja selaku perkumpulan orang yang percaya kepada Kristus masih memahami bahwa misi itu dilakukan oleh gereja hanya semata-mata untuk menambah jumlah anggota jemaat dalam gereja tersebut. Bahkan yang paling berbahaya adalah bahwa gereja memakai misi untuk tujuan tertentu, misalnya tujuan politik.

- Seringkali ada pandangan bahwa gereja tidak berurusan dengan hal-hal yang duniawi. Sebagai contohnya adalah bahwa gereja memahami kerusakan lingkungan hidup tidaklah menjadi tugas dan tanggung jawab gereja, yang berperan dalam menyelesaikan masalah lingkungan hidup ini adalah pemerintah. Menurut penulis ini merupakan pandangan yang salah dari gereja. Sebenarnya masalah lingkungan hidup ini merupakan tugas dan tanggung jawab bersama, yakni semua orang yang tinggal di planet bumi ini.

- Mengenai hal menjalankan misi juga gereja seringkali memahami bahwa misi untuk memberitakan kabar sukacita hanya bisa dilakukan kepada manusia saja. Menurut penulis ini merupakan paradigma yang salah. Sebenarnya kabar sukacita yang dibawa oleh Yesus sendiri ditunjukkan kepada seluruh ciptaan TUHAN agar semuanya turut merasakan damai sejahtera dari pengorbanan Yesus. Oleh sebab itu, melalui misi gereja seharusnya bisa menciptakan damai sejahtera di dunia ini dan bukan sebaliknya.

- Kerusakan lingkungan hidup yang makin hari makin memprihatinkan disebabkan oleh ulah manusia yang memiliki pola hidup yang kurang ramah lingkungan. Selain itu, kerusakan lingkungan hidup juga disebabkan oleh eksploitasi hasil alam yang berlebihan yang dilakukan oleh manusia tanpa mempertimbangkan akibat-akibat yang akan terjadi dari tindakan tersebut.

- Kepedulian gereja terhadap kerusakan lingkungan hidup sangat minim. Sejauh yang penulis lihat bahwa pada saat ini gereja lebih mementingkan hal-hal yang berkaitan dengan masalah internalnya dari pada masalah-masalah yang sedang terjadi di luar. Kerusakan lingkungan hidup ini sebenarnya merupakan bagian dari diri gereja yang bertumbuh dan berkembang di tengah-tengah dunia ini. Akan tetapi kekurang-pedulian gereja terhadap masalah ini bisa dikatakan sesuatu hal yang sangat fatal, karena akibat dari kerusakan lingkungan hidup sendiri akan dirasakan dampaknya oleh seluruh makhluk hidup yang ada di dalam dunia ini, termasuk gereja.

Alkitab menegaskan bahwa alam semesta diciptakan oleh Allah untuk tujuan yang luhur, yaitu untuk dimanfaatkan oleh manusia. Tetapi pemakaian ini bukan merupakan 
pemakaian yang tak bertanggung jawab, karena masih ada tujuan lainnya yaitu untuk dihuni oleh seluruh ciptaan secara bersama. Itu sebabnya Allah adalah Sang Pemilik dari bumi dan seluruh isinya, dan Dia berdaulat atas ciptaan-Nya tersebut. Manusia diciptakan sebagai bagian dari seluruh ciptaan, diberi tugas untuk menjaga dan memelihara bumi. Dalam Perjanjian Lama juga terdapat contoh yang menunjukkan bukti bahwa manusia seharusnya memelihara lingkungan adalah Imamat 25:3-7. Allah menghendaki orang Israel untuk mengistirahatkan lahan mereka setelah 6 tahun masa tanam. Maksud dari diadakannya sabat tanah ini agar:

- Umat Allah menyadari bahwa kedudukan bukan sebagai pemilik tanah-karena Allah adalah Sang Pemilik-melainkan hanya penyewa. Pemiliklah yang memiliki kuasa absolut atas tanahnya.

- Umat menyadari bahwa pengelolaan tanah harus berorientasi pada keberlangsungan hidup di masa yang akan datang. Allah menciptakan tanah tidak hanya untuk satu generasi, tetapi juga untuk kepentingan generasi yang akan datang.

Kerusakan lingkungan hidup adalah buah dari tindakan nir-etis manusia terhadap alam, dan juga tidak memandang hak generasi selanjutnya untuk menikmati berkat Allah dari alam. Mereka mengeksploitasi semaksimal mungkin untuk mendapatkan keuntungan ekonomis sebanyak mungkin. Oleh karena itu, titik tolak etika lingkungan yang teosentris dapat dikemukakan sebagai berikut. Pertama, adanya pengakuan bahwa segala sesuatu, termasuk manusia, adalah ciptaan Allah. Tetapi Allah tidak berhenti hanya pada penciptaan karena Dia merupakan Allah yang memelihara ciptaan-Nya. Di dalam tugas pemeliharaan ini, Allah mempercayakan pula kepada manusia, sehingga sudah sepatutnya manusia secara proaktif memelihara lingkungan. Kedua, penyalahgunaan kepemimpinan manusia atas ciptaan Allah merupakan bentuk keberdosaan manusia. Manusia semestinya tidak hanya memanfaatkan alam, tetapi harus melakukan pengelolaan pada saat yang bersamaan. Rusaknya lingkungan merupakan akibat dari manusia yang dipenuhi dengan kerakusan akan uang. Akibatnya alam hanya dipandang sebagai sumber ekonomi dengan mengorbankan pemeliharaan atas alam. Tugas gereja adalah menyadarkan umat agar tidak melakukan hal tersebut terhadap ciptaaan Allah lainnya.

Hendaknya gereja tidak reaktif dalam menangani permasalahan lingkungan hidup ini. Menurut Borrong, gereja harus proaktif untuk menciptakan dan memberikan pengajaran kepada umat agar mereka menjaga dan menghargai ciptaan Allah lainnya. ${ }^{24}$ Oleh karenanya gereja harus segera melakukan perubahan dengan cara:

- Memperlengkapi jemaat melalui pendidikan agar mereka menghargai ciptaan Allah yang lain.

- Membekali jemaat tentang bagaimana mengelola sampah, hal ini bertujuan untuk mengurangi kerusakan lingkungan hidup oleh sampah/limbah dari rumah tangga.

- Mengangkat tema-tema khotbah yang berkaitan dengan isu-isu lingkungan hidup.

- Mengadakan seminar/workshop yang berhubungan dengan lingkungan hidup dan cara mengelola sampah sehingga bisa menghasilkan uang. Hal ini juga akan menolong jemaat untuk mendapatkan penghasilan tambahan

24 Robert P. Borrong, "Kronik Ekoteologi: Berteologi dalam Konteks Krisis Lingkungan Hidup", Jurnal Stulos Vol.17 No.2 (Juli 2019): 208. 
dari mengkreasikan sesuatu yang berasal dari sampah.

- Gereja memberikan teladan dengan cara mengurangi penggunaan plastik/ styrofoam dalam setiap kegiatan yang ada di gereja.

- Menghijaukan area di sekitar gereja dengan menanam pohon atau tanamtanaman yang lain.

- Jika memungkinkan, gereja membuat bank sampah, seperti yang sudah dilakukan oleh beberapa gereja. Hal ini bisa mengubah paradigma jemaat bahwa sampah bisa diubah menjadi uang.

- Memanfaatkan kemajuan teknologi digital dalam memberikan pendidikan kepada jemaat serta mempromosikan setiap kegiatan kepedulian terhadap lingkungan ke media sosial gereja dengan tujuan menggugah kepedulian orang lain terhadap lingkungan apabila mereka melihat kegiatan tersebut.

Dari sisi jemaat yang merupakan gereja yang sebenarnya harus juga melakukan tindakan nyata dalam mengatasi kerusakan lingkungan hidup ini, dengan cara:

- Membudayakan buang sampah pada tempatnya serta memilah setiap sampah yang ada di dalam rumah.

- Menghijaukan lingkungan pekarangan rumah dengan menanam pohon atau tanam-tanaman yang lain.

- Menegur jika melihat orang yang tidak ramah lingkungan, seperti membuang sampah sembarangan, mengeksploitasi hutan, dll.

- Menghindari penggunaan Styrofoam/ plastik di dalam rumah tangga, seperti membawa tas/keranjang belanja sendiri ketika hendak berbelanja di pasar/super market.

- Mengelola sampah rumah tangga agar bisa menghasilkan uang, jemaat bisa mengikuti pelatihan-pelatihan yang ada, atau bisa juga melihat bagaimana caranya dari internet.

- Mengajak saudara ataupun rekanrekan yang lain agar mereka peduli terhadap kerusakan lingkungan, hal ini bisa dilakukan dengan cara memberikan edukasi kepada mereka tentang bagaimana seharunya manusia menghargai ciptaan Allah yang lain, serta apa akibat-akibatnya jika manusia itu tidak peduli terhadap kerusakan lingkungan hidup ini. Tentunya hal ini akan berhasil jika saudara telah melakukan hal itu terlebih dahulu, jika tidak maka mereka tidak akan melakukannya.

- Memposting setiap hasil karya maupun kegiatan yang berkaitan dengan kepedulian terhadap lingkungan hidup ke sosial media, agar orang lain terinspirasi dan mau peduli juga terhadap lingkungan.

Inilah yang seharusnya dilakukan oleh umat Allah sebagai ciptaan yang memiliki kelebihan khusus dibanding ciptaan Allah lainnya.

\section{Kesimpulan}

Kerusakan lingkungan hidup merupakan masalah yang paling serius dan harus segera ditangani dengan cepat. Oleh karenanya gereja mau tidak mau harus ikut beperan aktif dan memberi sumbangsih untuk menyelesaikan masalah tersebut dengan memberikan edukasi/pendidikan kepada jemaat tentang bagaimana sikap seorang Kristiani menghargai ciptaan Allah. Gereja harus memperbaiki diri dari kelalaian-kelalaian sekaligus gereja diharapkan mampu menggali ulang makna yang terdapat dalam Injil Markus 16:15 ini untuk memajukan misinya di tengah-tengah dunia ini, yakni bagaimana gereja mampu memelihara keutuhan setiap makhluk yang ada di muka bumi ini. 
Selain itu pemberitaan Injil yang hendak dilakukan oleh gereja jangan hanya sekedar berkata-kata atau hanya berkhotbah. Yang lebih daripada itu, pekabaran Injil harus dilakukan dengan tindakan nyata gereja, khususnya tindakan nyata dalam menangani kerusakan lingkungan hidup. Ada baiknya gereja menjadi contoh dan berada di barisan paling depan dalam menangani masalah lingkungan hidup ini. Jika hal ini tidak dilakukan oleh gereja, maka masa depan generasi berikutnya akan terancam, termasuk masa depan gereja. Untuk itu, kiranya hal ini menjadi beban bersama untuk tetap hidup bersahabat dengan lingkungan agar masa depan umat, masa depan gereja, serta masa depan generasi berikutnya mendapat kedamaian.

\section{Referensi}

Adinuhgra, Silvester. "Ekspoitasi Lingkungan Hidup dalam Perspektif Sollicitudo Rei Socialis (Sebuah Bentuk Keprihatinan Gereja)" Jurnal Sepakat Vol.3 No.1 (Desember 2016): 83-106.

Borrong, Robert P. Etika Bumi Baru. Jakarta: BPK Gunung Mulia, 2009.

Borrong, Robert P. et al., eds. Berakar di Dalam Dia dan Dibangun di Atas Dia. Jakarta: BPK Gunung Mulia, 2010.

Borrong, Robert P. "Kronik Ekoteologi: Berteologi dalam Konteks Krisis Lingkungan Hidup". Jurnal Stulos Vol.17, No.2 (Juli 2019): 183-212.

BP, Gereja: “Arti dan Perannya”. 2013. Diakses 1 April 2020. http://www.sarapanpagi.org/gerejaarti-dan-perannya-vt6452.html

Groenen, C. Pengantar ke dalam Perjanjian Baru. Yogyakarta: Kanisius, 2006.
Guthrie, Donald. Teologi Perjanjian Baru. Jakarta: BPK Gunung Mulia, 2010.

Henry, Matthew. Tafsiran Matthew Henry: Injil Markus. Surabaya: Momentum, 2011.

Ituma, Ezichi A. "Christocentric Ecotheology and Climate Change" Open Journal of Philosophy Vol.3 No.1a (Februari 2013): 126-130.

Leks, Stefan. Tafsir Injil Lukas. Yogyakarta: Kanisius. 2002.

MS. "Menggugah Warga Gereja Peduli Lingkungan”. PGI.or.id, 2014. Diakses 30 Maret 2020.

https://pgi.or.id/menggugah-wargagereja-peduli-lingkungan/

Nasution, P. "Pemanasan Global dan upaya-upaya sederhana dalam mengantisipasinya”. 2009. Diakses pada 20 April 2015, http://www.gogreenindonesiaku.co m/green_opinion1.php.

Pasang, Haskarlianus. Mengasihi Lingkungan: Bagaimana Orang Kristen, Keluarga dan Gereja Mempraktikkan Kebenaran Firman Tuhan untuk Menjadi Jawaban atas Krisis Ekologi dan Perubahan Iklim di Bumi Indonesia. Jakarta: Perkantas, 2011.

Sasmito, Paulus Erwin. "Melestarikan Lingkungan Hidup Secara Komprehensif'. Jurnal Orientasi Baru Vol.24, No.1 (April 2015): 3550.

Sirait, Bigman. Gereja yang Membumi. Jakarta: Yapama, 2015.

Sitompul, A.A. Manusia Dan Budaya. Jakarta: BPK Gunung Mulia, 2000.

Surbakti, Elisa B. Benarkah Yesus Juruselamat Universal? Jakarta: BPK Gunung Mulia, 2008.

Tomatala, Yakob. Teologi Misi. Jakarta: YT Leadership Foundation, 2003. 
PAK Gereja dalam Konteks Lingkungan....

Wahono, Satrio. "Etika Bumi dan Krisis Lingkungan". Tempo.com, 2020. Diakses 01 April 2020.

https://kolom.tempo.co/read/131318

8/etika-bumi-dan-krisis-

lingkungan/full\&view $=$ ok 
Jurnal Shanan

ISSN: 2549-8061

Volume 4 Nomor 1 Maret 2020 hal. 41-56 